\title{
THE RELATIONSHIP BETWEEN THE EXCHANGE RATE AND THE TRADE BALANCE IN SOUTH AFRICA
}

\author{
Lebogang Chiloane* \\ University of Johannesburg \\ mlchiloane@gmail.com \\ Marinda Pretorius \\ Ilse Botha+ \\ University of Johannesburg \\ University of Johannesburg \\ marindap@uj.ac.za \\ ilseb@uj.ac.za \\ Received: October 2012 \\ Accepted: June 2013
}

\begin{abstract}
The purpose of this paper is to test the existence of the J-curve effect and to show whether the Marshall-Lerner condition holds in the South African manufacturing sector. Using quarterly data from 1995 to 2010, the study uses the vector error correction modelling technique as well as impulse response functions to attain the research objectives. The results show that a long-run equilibrium relationship exists between the manufacturing trade balance and the three explanatory variables: real effective exchange rate, real domestic and foreign income levels. Overall, the results show that a depreciation in the domestic currency results in a deterioration in the manufacturing trade balance in the short run, and that this is followed by an improvement in the long run. The study finds evidence of the existence of the J-curve in the South African manufacturing sector. The long-run dynamics suggest that the Marshall-Lerner condition holds.
\end{abstract}

Keywords

J-curve, Marshall-Lerner, vector auto regression, trade balance, cointegration, impulse response function

*Ms L Chiloane is a masters student at the Department of Economics and Econometrics, University of Johannesburg, South Africa.

\#Ms M Pretorius is a lecturer in the Department of Economics and Econometrics, University of Johannesburg, South Africa.

+Prof I Botha is an associate professor in the Department of Finance and Investment Management, University of Johannesburg, South Africa. 


\section{INTRODUCTION}

The collapse of the Bretton Woods system of a fixed exchange rate led to the adoption of a flexible exchange rate regime by many countries, and South African was not an exception. A flexible exchange rate regime is currently being practised in South Africa, and this allows the exchange rate to be determined by demand and supply factors (Mtonga, 2011). Such a system results in large fluctuations in the exchange rate of the rand given the large volume of international market activities. As a result, it becomes difficult to predict the path towards exchange rate stability and hence its effects on the trade balance. This led to extensive interest among researchers regarding the relationship between exchange rate effects and the trade balance.

It is expected that a depreciation of the domestic currency will stimulate export demand and lower imports, thereby improving the trade balance. In contrast, an appreciation in the currency is expected to reduce exports demand and increase the demand for imports, and, consequently, adversely affect the trade balance. There is, however, a lag period before imports and exports can respond to particular changes arising from the foreign exchange rate market. This has implications in the short and long term, giving rise to the J-curve effect and the Marshall-Lerner condition respectively.

Analysis of South Africa's trade data shows that the total trade deficits that have been recorded over the recent years were mainly the result of large trade deficits recorded by the manufacturing sector. Although there are several factors that explain this deficit, the appreciation of the rand, especially, over the last two years resulted in the manufacturing sector being vulnerable to competition. For this reason, this study focuses on the manufacturing sector. According to IHS Global Insight (2011) trade statistics, manufacturing imports accounts for almost two-thirds of total imports of goods and about a third of total exports of goods.

The research question that this paper seeks to address is what are the effects of the real exchange rate of the rand on the South African manufacturing trade balance in the short and long run? This question will be answered by determining the existence of the J-curve effect and showing whether the Marshall-Lerner condition holds in the manufacturing sector. This will shed light on whether a mechanism of weakening the domestic currency would result in an improvement in the manufacturing trade balance.

The remainder of this paper is structured as follows. Section 2 gives an overview of the literature internationally and domestically. In section 3 , the data and methods to be used in the analysis are described. The model specification, estimation and results are presented in sections 4, 5 and 6 respectively and the paper concludes in section 7 .

\section{LITERATURE REVIEW}

Theoretically, it is expected that a depreciation in the domestic currency will stimulate export demand and lower imports, thereby improving the trade balance. In contrast, an appreciation in the currency is expected to reduce exports demand and increase the demand for imports and, consequently, adversely affect the trade balance. The effects of exchange rate fluctuations on the trade balance can be unpredictable at times and can contradict economic theory. This contradiction, as Magee (1973) explains, lies in the theory of the 'J-curve effect'. This theory suggests that there is a lag period before imports and exports could respond to particular 
changes arising from the foreign exchange rate market. According to this theory, as further explained by Bahmani-Oskooee and Ratha (2004), depreciation in a currency will initially worsen the trade balance, as higher prices of imports will counterbalance the reduced volume of imports, and the trade balance will only improve in the long run. As a result, the effect of exchange rate changes on the trade account might not conform to the J-curve theory in the short run. Another economic concept that explains the relationship between the exchange rate and the trade balance is the Marshall-Lerner condition. Appleyard and Field (1986) explain that, according to this condition, depreciation will improve the trade balance if the sum of the price elasticity of demand (in absolute values) for the countries' exports and imports exceeds one.

Eicher, Mutti, and Turnovsky (2009) argue that the Marshall-Lerner condition is not met in the short run because the demand elasticities are significantly smaller. This is because, in the short run, price changes have very little impact, if any, on the quantity of goods demanded as consumers take time to change their preferences. Although numerous studies on the effects of exchange rate changes on the trade balance are available in most countries, such empirical studies focusing on South Africa are lacking.

A number of studies have been conducted to assess the effects of exchange rate movements on the trade balance. These studies used different econometric techniques and variables to investigate the effects of exchange rate changes on the trade balance and whether a depreciation in the domestic currency first results in a deterioration in the trade balance and only improves it in the long run. This is done in order to investigate the presence of the J-curve effect. Available empirical studies on the subject have, however, produced mixed results.

In their study, Hacker and Hatemi-J (2004) conducted a study that tested the bilateral J-curve effects for three transitional central European countries, namely Czech Republic, Hungary and Poland, and their bilateral trade with Germany. The trade balances are calculated as a ratio of exports to imports, and they are explained by bilateral real exchange rates and domestic and foreign income levels. Using a vector error correction model (VECM) and impulse response functions, the study finds that the J-curve effect is observed for each of the countries as the trade balances briefly deteriorate after a depreciation in the real exchange rate and then improve in the long run.

In another study Tihomor (2004) employs an ARDL model to investigate Croatia's trade balance response to a permanent domestic currency depreciation. The real exchange rate, and domestic and foreign income levels are used as determinants of the trade balance. The trade balance is defined by the ratio of exports to imports. The study finds that a depreciation in the domestic currency adversely affects the trade balance initially. The trade balance then improves afterwards and reaches a new equilibrium level after 2,5 years. The responsiveness of the trade balance reflects the existence of the J-curve effect.

Akbostanci (2002) investigated the existence of the J-curve effect in Turkey. The trade balance is defined as a function of the real exchange rate, and domestic and foreign income. The results of the estimation, based on cointegration analysis, VECM and impulse responses, show that the trade balance for Turkey improves immediately after the domestic currency has depreciated and then worsens and improves again in the long run. This reflects the non-existence of the J-curve pattern.

While most studies use bilateral country-based data, studies focusing on the responsiveness of sectors or industries' trade balances to exchange rate changes is limited. To add more value to the study by Akbostanci (2002), which is based on Turkey's aggregate data, Yazici (2008) 
conducted research based on disaggregated data according to sectors. The objective of that study was to examine the response of the Turkish agriculture, manufacturing and mining sectors' trade balances to changes in the domestic currency. Using the polynomial distributed lag model, the study finds that although the response of all sectors exhibits the same pattern, the time period it takes to worsen and improve the trade balances differs across sectors. On average, a depreciation in the currency leads to the trade balances in all sectors first improving, then worsening and improving again. In the long run, the trade balances of manufacturing and mining sectors improve, while those of the agricultural sector worsen. The J-curve effect is not observed, as the depreciation seems to positively affect the trade balances in the short run. Although the two recently reviewed studies on Turkey use different data, they produce the same results, especially in the short run where the trade balances do not worsen immediately after the domestic currency has depreciated as required by the J-curve phenomenon.

Bahmani-Oskooee and Kovyryalova (2008) conducted a study that examined the short- and long-run effects of fluctuations in the real United States (US) dollar-British pound exchange rate on 117 industries in the United Kingdom (UK) that traded with the US. Their results, which were based on the bound testing approach, show that, in the short run, $60 \%$ of the industries' trade balances responded negatively to the depreciation in the exchange rate. The short-run effects lasted into the long run only in 66 industries, reflecting the existence of the J-curve.

Carter and Pick (1989) take a different approach by not focusing directly on the impact of exchange rate on the trade balance in order to investigate the J-curve effect. Instead, their study first investigated the exchange rate pass-through effects on import and export unit values, and the net impact of these changes on the trade balance. Their study is based on the US's agricultural sector. Agricultural export and import unit values are used as factors determining the trade balance, and the polynomial distributed lag model is used in the estimation process. The results of the empirical study show that following a $10 \%$ cent depreciation on the US dollar, the sector's trade balance worsened during the first nine months and then improved thereafter. This results show that the J-curve effect is present.

Other studies conducted on trade flows in South Africa include those by Bah and Amusa (2003) and Takaendesa, Tsheole and Aziakpono (2006). However, the focus of their empirical studies was on the effect of real exchange rate volatility on South Africa's exports only and they disregarded imports. In its empirical study, the International Monetary Fund (IMF) (2006) found that the elasticities of export values in emerging markets tended to be small, and that most of the trade balance response to exchange rate changes came from the behaviour of imports. Hence, it is necessary to estimate both the imports and exports price elasticities to be able to assess the impact of the domestic currency movements on the trade balance.

Knowing only the impact of changes in the exchange rate of the rand on exports is not sufficient to understand the effect of currency fluctuations on the overall trade balance. To redress the shortcoming, Kamoto (2006) investigated the effects of the exchange rate on the trade balance in South Africa and Malawi using data from the first quarter of 1976 to the fourth quarter of 2003. Using the vector error correction model (VECM), the study finds that there is a negative short-run and a positive long-run relationship between the trade balance and exchange rate in South Africa. This reflects the existence of the J-curve, as the South African trade balance first deteriorates after currency depreciation and only improves in the long run. There is, however, a lack of information on the specific bilateral trading partners and sectors that support the existence of the J-curve effect. This is crucial, as there has to be a specific trading partner, sector or industry for a policy intervention to be successful. In contrast, despite finding a long- 
run positive effect between the Real Effective Exchange Rate (REદR) and the Malawian trade balance, there is no evidence of the J-curve effect. This is because the study finds that a depreciation in the Malawian currency does not result in a deterioration in the country's trade balance in the short run, which would satisfy the J-curve effect phenomenon.

A similar and more recent South African study is the one conducted by Moodley (2010), where the relationship between the exchange rate and the South African trade balance with Brazil, Russia, India and China is examined. The study uses a sample period from the first quarter of 1994 to the fourth quarter of 2009. Using Autoregressive Distributed Lag (ARDL) models, consisting of real exchange rate, and domestic and foreign income as explanatory variables, the study finds that there is no relationship between the real exchange rate and South Africa's trade balance with Brazil, China and India. In contrast, a positive long-run relationship between the real exchange rate and South Africa's trade balance with Russia was found. The findings, however, reveal no existence of the J-curve effect between the domestic trade balance and the trade balances of all four trading partners.

The analysis of the relationship between changes in exchange rate movements and trade flows performed on aggregate data has the potential to result in inconclusive and biased results. Available empirical literature on the J-curve effect in South Africa is based on the overall trade balance, and research focusing on different sectors of the economy is lacking. This results in uncertainties about the nature of the relationship and the overall impact of exchange rate fluctuations of the rand on trade flows of different sectors. The impact differs from one commodity to the other and also across various sectors. Fouquin, Sekkat, Mansour, Mulder and Nayman (2001) attribute this to differences in operating strategies and market structures. The objective of this paper is therefore to focus specifically on the manufacturing sector of South Africa.

\section{DATA AND DEFINITION OF VARIABLES}

This study uses quarterly data from the first quarter of 1995 to the fourth quarter of 2010 . To effectively determine whether a depreciation of the domestic currency improves the trade balance in the long run and worsens it in the short run the sample period includes the 2007/2008 global financial crises. The inclusion of this period in the sample period implies volatility in terms of the domestic currency and income levels of major trading partners, which is important in determining if the ML condition holds and if the J-curve effect is present. All variables are transformed to their natural logarithm in order to be able to estimate the elasticities required to assess the impact of the real exchange rate on the trade balance of the manufacturing sector. The manufacturing real trade balance is defined by the ratio of real exports to real imports. The import and export data was obtained from South African Customs and Excise, and was extracted from the IHS Global Insight database. This is nominal data measured in South African rands. In order to convert the data into real terms, the nominal data can be deflated by each sector's respective PPI for exported and imported commodities. According to the IMF (2010a), the PPI for imported and exported commodities is an important indicator that can be used to deflate a series of nominal values of products traded in order to provide measures of changes in their volumes. However, owing to the unavailability of historical PPI data according to sectors, the nominal manufacturing imports and exports values are deflated by the total import and export rand prices. These prices were sourced from the SARB online statistical database. 


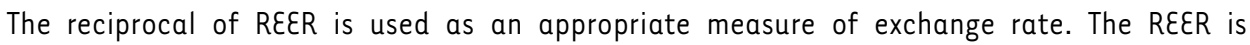
calculated on the basis of South Africa's trade flows of manufactured goods with its main trading partners (SARB, 2008). The data for REદR together with that of real GDP, with the latter used as a proxy for domestic income, was sourced from the SARB online statistical database. The real GDP of South Africa's main trading partners was used as a proxy for foreign income. These trading partners are the Euro area, US, UK and Japan. The times series was sourced from the Organisation for Economic Cooperation and Development (OECD) and is reported as the real GDP index. The real GDP data for all the selected trading partners is first adjusted by indexing to 2005 as a base year. This is followed by integrating the data into a single index using the weights calculated by the SARB (2008) in the calculation of the REER. The total weights of the selected trading partners amounts to approximately $70 \%$. The calculated index then reflects the weighted average of real GDP for the main trading partners. This calculation is similar to that employed by Tihomor (2004) and Alawattage (2005).

\section{MODEL SPECIFICATION}

The trade balance model formulated by Yusoff (2009), Yazici (2008), Bahmani-0skooee and Wang (2006) and Hacker and Hatemi-J (2004) was adopted. The model specifies the manufacturing trade balance as a function of real exchange rate, real domestic income and real foreign income. The empirical model is specified as

$$
\ln (T B)=\alpha+\theta \ln \left(R E E R_{t}\right)+\gamma \ln \left(Y D_{t}\right)+\beta \ln \left(Y F_{t}\right)+\varepsilon_{t}
$$

where the variables and parameters are defined as:

$T B$ = the manufacturing real trade balance, defined as the ratio of exports to imports

$R \varepsilon \varepsilon R=$ reciprocal of the real effective exchange rate of the South African rand

$Y D=$ domestic income measured by real GDP

$Y F \quad=$ foreign income measured by the major trading partner's real GDP

$\alpha, \theta, \gamma$, and $\beta_{i}$ are the parameters to be estimated; $\varepsilon_{t}$ is the error term, and captures all other factors that are not been included in the model but have an influence on the dependent variable (trade balance). It is important to note that $\theta$ measures the exchange rate elasticity of the trade balance.

According to Yusoff (2009), $\theta$ provides sufficient information to assess whether the MarshallLerner condition is satisfied. Therefore, it is not necessary to estimate the import and export demand equations individually, as they are both taken into account in formulating the trade balance equations. Regarding the expected signs, the sign for $\theta$ can either be negative or positive, depending on the nature of the responsiveness of trade flows to changes in exchange rate movements. In addition, it is also crucial to note that the sign depends on the method of quotation used to express the exchange rate. According to Wang (2005) an increase in the exchange rate, when quoted using the direct method, reflects a depreciation in the domestic currency, while, when an indirect quotation is used, an increase in the exchange rate level shows an appreciation of the local currency. In South Africa, the REદR index is based on an indirect method, where a decrease in the index is associated with a depreciation in the local currency, while an increase in the index reflects an appreciation in the domestic currency. In order to simplify the analysis, the reciprocal of REER is used in estimating equation 1 , such that an 
increase in REદR reflects a depreciation in the domestic currency, while a decrease reflects an appreciation. This calculation is adopted from Chai-anant and Jantarangs (2004), who in their investigation of developments and key determinants of Thailand's current account use the reciprocal of REદR as one of the determinants and argue that it is useful as it simplifies the analysis of impulse responses. Therefore a positive sign for $\theta$ will satisfy the Marshall-Lerner condition. This means that a depreciation in the domestic currency will improve the manufacturing trade balance in the long run. This long-run effect is similar to the J-curve phenomenon. The J-curve, however, differs from the Marshall-Lerner condition, as the latter focuses only on the long-run condition. For a J-curve effect to exist, the short-run condition is that $\theta$ be negative, such that a depreciation in domestic currency should lead to a deterioration in the trade balance.

An increase in domestic income leads to a rise in the demand for foreign-produced goods, and, as this happens, the trade balance should deteriorate. Therefore, the coefficient for $\gamma$ is expected to be negative. Magee (1973), however, argues that the trade balance can also improve following a rise in domestic income levels. This could occur when domestic production of imported products rises faster than the consumption of these goods. It can therefore be concluded that the sign of real domestic income could either be negative or positive. The expected sign for the coefficient of foreign income, $\beta$, is ambiguous, as the impac $t$ of foreign income on domestic trade balance could be negative or positive. Higher foreign income may increase the foreign country's imports from South Africa, which is an increase in the domestic exports. All things being equal, this results in an improvement in the trade balance; thus a positive sign for $\beta$ could be expected. In contrast, a rise in foreign income may reduce the foreign countries' imports from South Africa due to growth in import-substitute production in the foreign countries. A decline in South Africa's exports could bring about a deterioration of the trade balance. If this prevails, a negative sign is expected for $\beta$.

\section{ESTIMATION TECHNIPUE}

This section discusses the empirical methodology to be applied in this paper. The Johansen (1991) cointegrating techniques together with the VECM procedures are employed. The use of the Johansen approach requires that the order of integration of the variables be tested first - that is, unit roots tests must be performed. This is a crucial step, since estimation on non-stationary variables might result in spurious results that could be misleading. The Augmented Dickey-Fuller (ADF) (Dickey and Fuller, 1981) and Phillips-Perron (PP) (Phillips and Perron, 1988) tests are employed as formal tests under the null hypothesis that the time series have a unit root.

Having tested the unit root characteristics of the variables, the next step is to investigate the existence of any linear combination of the time series, which is equivalent to determining the number of cointegrating vector(s). This is important in this paper in order to ensure that the variables or series included in the estimated model do not drift away in opposite directions for a long time without returning to a specific mean. The Johansen cointegration test requires that the optimal lag order be chosen prior to testing the null hypothesis of no cointegration. The Akaike Information Criterion (AIC) and Schwarz Information Criterion (SC) are used to select the optimal lag length which is used determine the number of cointegrating vectors in the system. The cointegration test is based on the trace test $\left(\lambda_{\text {trace }}\right)$ and the maximum eigenvalue $\left(\lambda_{\max }\right)$. The null hyphothesis of no cointegration is rejected if the calculated $\lambda_{\text {trace }}$ and $\lambda_{\max }$ are greater than the corresponding critical values at a specific level of significance. If that prevails, it can 
therefore be concluded that the variables in equation 2 have a long-run relationship and therefore the number of cointegrating vectors can be identified.

If the variables are found to be cointegrated, then the next step is to estimate the cointegrating vector normalised with respect to the manufacturing trade balance. The short-run effects of exchange rate movements are incorporated into the long-run equation by estimating the VECM. The VECM also captures the speed at which the dependent variable, the trade balance, adjusts towards long-run equilibrium.

Lal and Lowinger (2002) and Kalyoncu, Ozturk, Artan and Kalyoncu (2009) affirm that the best way to find evidence of the possible existence of the J-curve is to use the impulse response functions. These functions are important in showing the dynamic relationships between variables, as they will provide insights into the response of a variable to unexpected shocks in other variables in the system over a period. The last step to be carried out is the measurement of the relative importance of each shock to the variables in the model. This is done by assessing the variance decomposition.

\section{ANALYSIS OF RESULTS}

TABLE 1 below provides the unit root test results based on the ADF and PP tests. The testing procedure is based on an unknown data-generating process.

TABLE 1: Unit root tests

\begin{tabular}{lllllll}
\hline & ADF unit root test & & & \multicolumn{2}{c}{ Phillips Perron unit rootest } \\
& Specification & Level & $\begin{array}{c}\text { First } \\
\text { Difference }\end{array}$ & Specification & Level & $\begin{array}{c}\text { First } \\
\text { Difference }\end{array}$ \\
\hline LNTB & Trend and Intercept & -1.99 & $-7.41^{\star}$ & Trend and Intercept & -2.44 & $-11.05^{\star}$ \\
LNREER & Trend and Intercept & -2.50 & $-3.30 * \star$ & None & -2.08 & $-7.41^{\star *}$ \\
LNYD & Intercept & -1.83 & $-3.97 *$ & Intercept & -1.83 & $-3.44^{\star}$ \\
LNYF & Intercept & -2.56 & $-10.49 *$ & Intercept & -2.00 & $-3.97^{\star}$ \\
\hline
\end{tabular}

Source: Eviews results

* and $* \star$ denote the rejection of the null hypothesis at a $5 \%$ and $10 \%$ level of significance respectively

Critical values at a $5 \%$ level of significance: None: -1.95 ; Intercept: -2.91 ; Trend and Intercept: -3.48 .

Critical values at a $10 \%$ level of significance: None: -1.62 ; Intercept: -2.59 ; Trend and Intercept: -3.17 .

The results of the ADF and PP tests indicate that the null hypothesis of containing a unit root for all level data is not rejected. The null hypothesis is, however, rejected on the first difference for all the variables. This then allows one to conclude that all the variables are integrated of the first order, that is, they are all I(1).

Because the variables are integrated of the same order, the cointegration test is performed. Before doing this, the lag order is selected. The AIC and SC information criterion selected different lag orders, with the former selecting two lag orders while the SC information criterion selected one lag order. The $\mathrm{SC}$ information criterion seems to be providing the lag length of the 
VAR that minimises the information criterion, as the lag selected is lower than that selected by the AIC. In his study, which investigated the type of selection criterion to employ when selecting the lag length, Liew (2004) found that AIC was more robust in a sample of lower than 60 . In this paper the number of observations is 64 , thus affirming that $\mathrm{SC}$ has selected an appropriate lag. For these reasons, an appropriate lag order was chosen by using the SC information criterion which selected one lag length. A lag order of one was then used to carry out the Johansen cointegration under the null hypothesis of no cointegration $(r=0)$. TABLE 2 reports the results of the cointegration tests based on the trace test trace test $\left(\lambda_{\text {trace }}\right)$ and the maximum eigenvalue test $\left(\lambda_{\max }\right)$.

TABLE 2: Johansen cointegration rank test with optimal lag length of one

\begin{tabular}{llccccccc}
\hline & & \multicolumn{3}{c}{ Trace test } & \multicolumn{3}{c}{ Maximum eigenvalue test } \\
$\begin{array}{c}\text { Number of } \\
\begin{array}{c}\text { cointegrating } \\
\text { equations }\end{array}\end{array}$ & Eigenvalue & Statistic & $\begin{array}{c}\text { Critical } \\
\text { Value }\end{array}$ & Prob. & Statistic & $\begin{array}{c}\text { Critical } \\
\text { Value }\end{array}$ & Prob. \\
\hline None & 0.411199 & 65.97826 & 63.87610 & 0.0329 & 32.83941 & 32.11832 & $0.0407 *$ \\
At most 1 & 0.232191 & 33.13886 & 42.91525 & 0.3295 & 16.38126 & 25.82321 & 0.5110 \\
At most 2 & 0.149128 & 16.75760 & 25.87211 & 0.4333 & 10.01261 & 19.38704 & 0.6175 \\
At most 3 & 0.103081 & 6.744989 & 12.51798 & 0.3719 & 6.744989 & 12.51798 & 0.3719 \\
\hline
\end{tabular}

Source: Eviews output

* denotes rejection of the hypothesis at the .05 level

The cointegration test results indicate that the null hypothesis of no cointegration $(r=0)$ is rejected, as both $\lambda_{\text {trace }}$ and $\lambda_{\max }$ statistics are found to be greater than the critical values at a $5 \%$ level of significance. The two tests indicate that there is one cointegrating equation, reflecting that there is a long-run relationship between the manufacturing trade balance, REER, and real domestic income and foreign income.

Following the findings that suggested that a long-run relationship exists in the variables included in equation 2, a VECM is then estimated with a lag order of one. The long-run equation when normalised by the coefficient of the manufacturing trade balance can be written as follows:

$$
\begin{aligned}
& \ln T B=6.84+0.77 \ln R \varepsilon \varepsilon R-3.77 \quad \ln \mathrm{Y} D+2.20 \quad \ln \mathrm{YF} \\
& {[5.41] * \quad[-6.65] \text { * }[3.85] \text { * }}
\end{aligned}
$$

where the values in the parentheses are the t-statistics of the estimated coefficients, while * denotes rejection at a $5 \%$ level of significance.

The estimated long-run coefficient of $\ln R \varepsilon \varepsilon R$, which is 0.77 , is positive and significant, showing that depreciation in the domestic currency has a positive impact on the manufacturing trade balance. Put differently, an increase in the REદR of the rand (depreciation) leads to an improvement in the manufacturing trade balance in the long run, while a decrease in the REદR of the rand (appreciation) leads to a deterioration in the manufacturing trade balance in the long run. The improvement of the trade balance following exchange rate depreciation provides sufficient empirical evidence that the Marshall-Lerner condition holds, implying that 
depreciation in the domestic currency is effective in improving the manufacturing trade balance. This conclusion will, however, be confirmed by the results of the impulse response functions.

The size and sign of the estimated coefficient for InRE६R are comparable to other studies done on South Africa and other developing economies. Kamoto (2006) estimated a relatively comparable coefficient of -0.62 with regard to the impact of the REER of the rand on the South African total trade balance. In his study on the impact of the REદR on Pakistan's trade balance, Asif (2011) finds that a $1 \%$ rise (decrease) in the effective exchange rate could worsen (improve) the trade balance by $0.64 \%$.

The estimated coefficient of real domestic income is negative and significant, reflecting that a rise in South Africa's income results in a deterioration in the trade balance. Duasa (2007) argues that the negative sign of domestic income supports the Keynesian view that an increase in domestic income leads to a rise in the demand for foreign-produced goods and adversely affects the trade balance. The estimated coefficient of InYF is positive and significant, showing that an increase in the income of South Africa's major trading partners leads to an improvement in South Africa's manufacturing trade balance. In addition, an increase in foreign income could lead to a rise in foreign demand for South African-produced goods, and thus improve the domestic trade balance. The larger estimated long-run coefficient of domestic income relative to that of foreign income is in accordance with the structure of the domestic manufacturing sector. The sector is a net importer. Therefore, domestic income explains a large portion of the trade balance for manufactured goods relative to the impact of foreign income. The estimated signs are in accordance with economic theory, as it has been mentioned in the earlier section that the effects of both domestic and foreign income on the trade balance can take two forms.

The error correction term, which measures the speed of adjustment to long-run equilibrium, is important to analyse in the VECM's results. The error correction term is significant, has the correct negative sign (stable adjustment coefficients that moves back to equilibrium) and the value of the term lies within the relevant range of 0 and -1 as required. The results based on the error correction term show that about $65 \%$ of the disequilibrium in the manufacturing trade balance is corrected each quarter. This means that the speed of adjustment for the manufacturing trade balance in returning to equilibrium is quick (it takes only about 1,5 quarters).

In order to determine if the J-curve exists, a short-run model is specified and estimated using the Ordinary Least Squares (OLS) method. In the model the difference of the manufacturing trade balance, which is regarded as a dependent variable, is specified as a function of the lagged first difference of REER, real domestic and income. The model is specified as follows:

$$
\Delta \ln \left(T B_{j_{t}}\right)=\alpha_{0 j}+\theta_{i} \Delta \ln \left(R E E R_{(t-1)}\right)+\gamma_{i} \ln \Delta\left(Y D_{t-1}\right)+\beta_{i} \Delta \ln \left(Y F_{t-1}\right)
$$

where all other variables remained as previously defined, $\Delta$ denotes change, $t-1$ refers to the previous quarter.

Equation 3 was estimated, and the diagnostic test revealed that there is no heteroskedasticity present and that the residuals are normally distributed. In contrast, the null hypothesis of no serial correlation was rejected on a $5 \%$ level of significance, suggesting evidence of serial correlation. Gujarati (2003) indicates that when there is serial correlation in the data - that is, when errors are correlated - the OLS estimation results provide unbiased estimates of standard errors. He further suggests that the Newey-West method could be used in order to correct the 
standard errors of the estimated coefficients. In doing so, equation 3 was re-estimated using the Newey-West method, and the results are presented in TABLE 3.

TABLE 3: Short run elasticities - Newey-West method

\begin{tabular}{lcccc}
\hline \multicolumn{1}{c}{ Variable } & Coefficient & Std. Error & t-Statistic & Prob. \\
\hline D(LNREgR) & -0.407048 & 0.194392 & -2.093957 & 0.0410 * \\
D(LNyD(-3)) & -4.519293 & 1.512671 & -2.987625 & $0.0042 *$ \\
$D($ LNYF(-5)) & 6.256548 & 2.06004 & 3.0371 & $0.0037 *$ \\
C & 0.009062 & 0.008445 & 1.073037 & 0.288 \\
\hline
\end{tabular}

\section{Source: Eviews output}

* denotes rejection of the hypothesis at the .05 level

The short-run model shows that the manufacturing trade balance in a particular quarter is determined by the RहદR of that same quarter, the third quarter lag of real domestic income and the fifth quarter lag of real foreign income. The results show that real domestic and foreign income take time to filter through the domestic economy. The model estimated short-run negative relationships between the manufacturing trade balance and the REER. This shows that, in the short run, an increase in the REદR, reflecting a depreciation in the domestic currency, leads to a deterioration in the manufacturing trade balance. These short-and long-run results suggest that the J-curve exists. This signifies that a depreciation in the local currency does not result in a short-run improvement in the trade balance as general economic theory suggests. Instead, the depreciation of the rand, measured by a rise in the reciprocal of the REER index, results in a deterioration in the manufacturing trade balance in the short run, and an improvement in the long run.

The finding with regard to the existence of the J-curve in the South African manufacturing sector is similar to that of Kamoto (2006), although his study is based on aggregated data. In his research, which investigates the J-curve effect in the total trade balance in South Africa, Kamoto (2006) found that the J-curve pattern was observed in South Africa. Because his study provides little evidence of the sectors that could be contributing to his findings, the results in this current paper suggest that the manufacturing sector's trade balance contributes to the existence of the J-curve effect in the total trade balance in South Africa.

Impulse response functions are performed to provide more insights into the dynamics of the explanatory variables - especially real exchange rate, which is a key independent variable in this study. The following Cholesky ordering is employed: LNREER, LNYD, LNYF, LNTB. The impulse responses are shown in FIGURE 1. 
Response to Cholesky One S.D. Innovations

Response of LNTB to LNTB

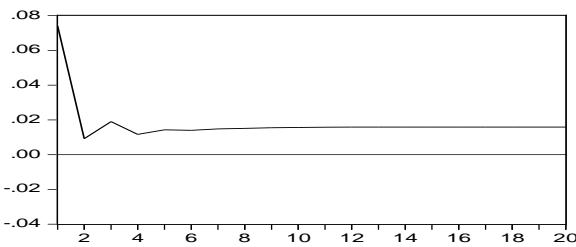

Response of LNTB to LNYD

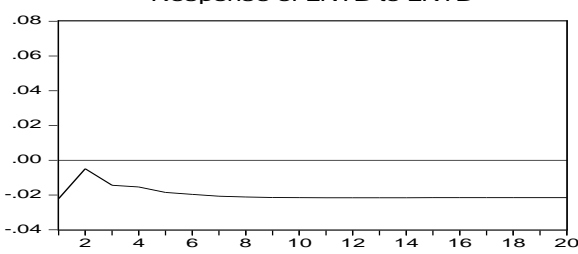

Response of LNTB to LNREER

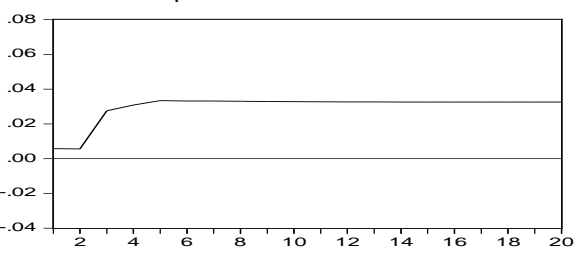

Response of LNTB to LNYF

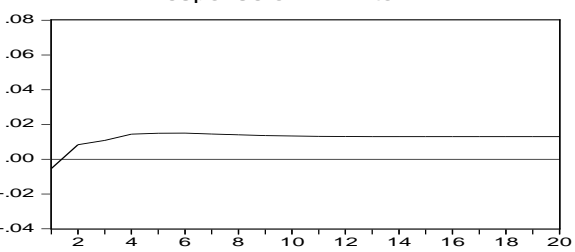

\section{FIGURE 1: Impulse response functions}

\section{Source: Eviews output}

Analysis of the impulse response functions reveals that the manufacturing trade balance deteriorates during the first quarter when the explanatory variables are individually shocked. In particular, the trade balance initially deteriorates following shocks in the REદR, with the rate of deterioration remaining constant during the second quarter. Shocks in the REદR show a notable positive impact on the trade balance in the third quarter, with the trade balance starting to improve at a slower pace thereafter, before remaining constant from the eighth quarter. Further analysis shows that a shock in the domestic income leads to an immediate deterioration in the manufacturing trade balance. This negative effect becomes smaller in the second quarter. The worsening in the trade balance continues during the following quarters before remaining constant from approximately the tenth quarter. In addition, FIGURE 1 reveals that although a shock in the foreign income of South Africa's major trading partners leads to an immediate deterioration in the manufacturing trade balance, this negative impact is short-lived. The negative impact on the trade balance rebounds in the second quarter as the trade balance improves thereafter. The shock in foreign income continues to have a positive impact afterwards, with the trade balance for the manufacturing sector improving at a slower pace each quarter before stabilising at around the eleventh quarter.

Overall, the estimated long-run coefficients obtained from the cointegrating equations correspond to the long-run findings of the impulse response functions that positive relationships exist between the manufacturing trade balance and the RE\&R, as well as the manufacturing trade balance and foreign income. The findings are also similar in estimating the negative relationship found between the manufacturing trade balance and domestic income. In the short run, only the REER is significant in explaining the manufacturing trade balance, and the relationship between these two variables is negative. The short-run negative and long-run positive relationships between the trade balance and the REદR suggest that the J-curve exists, while the long-run effects show that the Marshall-Lerner condition holds.

The next step is to examine the relative importance of the shocks in each of the explanatory variables on the manufacturing trade balance by analysing the results of the variance 
decomposition presented in TABLE 4 below. In order to be able to assess long period effects, the study allows the variance decomposition for 20 quarters (five years).

TABLE 4: Variance decomposition of the manufacturing trade balance

\begin{tabular}{|c|c|c|c|c|c|}
\hline Period & S.E. & LNREER & $\angle N Y D$ & $\angle N Y F$ & $\angle N T B$ \\
\hline 1 & 0.056142 & 0.556786 & 8.115908 & 0.468182 & 90.85912 \\
\hline 2 & 0.081801 & 1.050162 & 8.224509 & 1.584218 & 89.14111 \\
\hline 3 & 0.097694 & 10.78716 & 9.360266 & 2.816441 & 77.03613 \\
\hline 4 & 0.110617 & 19.35953 & 10.35167 & 4.607572 & 65.68122 \\
\hline 5 & 0.122247 & 26.13386 & 11.66346 & 5.836741 & 56.36594 \\
\hline 6 & 0.133169 & 30.78500 & 12.90898 & 6.703565 & 49.60246 \\
\hline 7 & 0.143475 & 34.13469 & 14.06135 & 7.223409 & 44.58056 \\
\hline 8 & 0.153217 & 36.62525 & 15.06025 & 7.543151 & 40.77135 \\
\hline 9 & 0.162438 & 38.55057 & 15.91126 & 7.736320 & 37.80185 \\
\hline 10 & 0.171192 & 40.08618 & 16.62794 & 7.859563 & 35.42631 \\
\hline 11 & 0.179528 & 41.34396 & 17.23170 & 7.942690 & 33.48165 \\
\hline 12 & 0.187497 & 42.39671 & 17.74271 & 8.003477 & 31.85710 \\
\hline 13 & 0.195138 & 43.29324 & 18.17874 & 8.051207 & 30.47681 \\
\hline 14 & 0.202490 & 44.06733 & 18.55428 & 8.090942 & 29.28745 \\
\hline 15 & 0.209582 & 44.74317 & 18.88084 & 8.125307 & 28.25069 \\
\hline 16 & 0.216440 & 45.33862 & 19.16744 & 8.155720 & 27.33823 \\
\hline 17 & 0.223086 & 45.86729 & 19.42110 & 8.182976 & 26.52863 \\
\hline 18 & 0.229540 & 46.33980 & 19.64731 & 8.207572 & 25.80531 \\
\hline 19 & 0.235816 & 46.76462 & 19.85040 & 8.229860 & 25.15512 \\
\hline 20 & 0.241930 & 47.14857 & 20.03380 & 8.250118 & 24.56752 \\
\hline
\end{tabular}

Source: Eviews output

TABLE 4 shows that about $91 \%$ of the forecast error variances of the manufacturing trade balance are explained by its own innovations during the first quarter. This decreases to about $89 \%$ in the second quarter and continues to decline gradually over time as this is offset by the importance of other independent variables. Among the three determinants, the REદR seems to be the main determinant of the trade balance, as its relative importance in affecting the manufacturing trade balance increases at a faster pace each quarter when compared to real domestic and foreign income. During the tenth quarter, fluctuations in the RहદR explain approximately $40 \%$ of the forecast error variance. Over the same period, domestic and foreign income explains about $17 \%$ and $8 \%$ respectively of the forecast error in the manufacturing trade balance. By almost the fifth year, the REદR of the rand starts to explain almost half of the innovations in the trade balance. The trend results of the variance decompositions are similar to 
those found by Kamoto (2006), where the trade balance explains a larger portion of its own innovations, and over a period of three years the REદR starts to explain a significant proportion of the variations in the trade balance.

\section{SUMMARY AND CONCLUSION}

The purpose of this study was to investigate the short- and long-run effects of the REहR of the rand on the South African manufacturing trade balance. Employing Johansen cointegration, $V \varepsilon C M$ and impulse responses, the study finds that the short-run effects of the REहR on the manufacturing trade balance are different from the long-run effects. In particular it is found that the REદR is negatively related to the manufacturing trade balance in the short run, while a positive relationship exists in the long run. This shows that a deterioration in the external value of the domestic currency initially leads to a deterioration in the manufacturing trade balance, and an improvement thereafter. The empirical results provide evidence of the J-curve effect and demonstrate that the Marshall-Lerner condition hold in South Africa's manufacturing sector. A long-run negative relationship was found between real domestic income and the manufacturing trade balance, indicating that a rise in real domestic income leads to a deterioration in the sector's trade balance. In contrast, a long-run positive relationship was found between the manufacturing trade balance and real foreign income.

The VECM estimation revealed that that about $65 \%$ of the disequilibrium in the manufacturing trade balance is corrected each quarter. Shocks in the real exchange rate are shown to impact greatly on the manufacturing trade balance when compared to the other two variables. In addition, it has also been found that fluctuations in the REદR explain a large portion of the forecast error variance of the manufacturing trade balance over time when compared to the two other determinants. This makes sense, because the manufacturing sector is sensitive to exchange rate changes.

In its country report study, the IMF (2010b) found that the real exchange rate of the rand could be overvalued by between $5 \%$ and $15 \%$. The findings of this paper suggest that policy intervention in the form of depreciating the external value of the domestic currency aimed at improving the country's exports should be sector-targeted, and that such a policy intervention could be effective in improving the manufacturing sector's trade balance. Further research could adopt an alternative approach, using the disaggregated data with a specific focus on certain industries within the manufacturing sector. This will assist in determining the specific industry or industries that policy intervention should be targeting.

\section{LIST OF REFERENCES}

Akbostanci, દ. (2002). Dynamics of the trade balance: The Turkish J-Curve. ERC, Middle East Technical University. (Working Paper in Economics no. 01/05).

Alawattage, U.P. (2005). Exchange rate, competitiveness and balance of payment performance. Central Bank of Sri Lanka Staff Studies, 35(182), pp. 63-91.

Appleyard, D.R. \& Field, A. (1986). A note on teaching the Marshall-Lerner condition. Journal of Economic Education, 17(1), pp. 52-56. 
Asif, M. (2011). Impact of devaluation on trade balance in Pakistan. Economic of Knowledge, 3(3), pp. 16-25.

Bah, I. \& Amusa, H.A. (2003). Real exchange rate volatility and foreign trade: Evidence from South Africa's exports to the US. The African Finance Journal, 5(2), pp. 1-20.

Bahmani-Oskooee, M. \& Kovyryalova, M. (2008). The J-Curve: Evidence from industry trade data between US and UK. Economic Issues, 13(1), pp. 25-44.

Bahmani-0skooee, M. \& Ratha, A. (2004). The J-Curve: A literature review. Applied Economics, 36(13), pp. 1377-1398.

Bahmani-Oskooee, M. \& Wang, Y. (2006). The J-Curve: China versus her trading partner. Bulletin of Economic Research, 58(4), pp. 323-34.

Carter, C.A. \& Pick, D. H. (1989). The J-curve and the US agricultural trade policy. American Journal of Agricultural Economics, 71 (3), pp. 712-720.

Chai-anant, C. \& Jantarangs, C. (2004). Thailand's current account adjustment: Development and responses to economic tools. Monetary Policy Group, Bank of Thailand Symposium, 2004. [Online] Available: http://www. econ.tu.ac.th/.../Thailand's\%20Current\%20\%20Account\%20Adjustment.pdf. (Accessed 29 October 2011).

Dickey, D.A. \& Fuller, W.A. (1981). Likelihood ratio statistics for autoregressive time series with a unit root. Econometrica. 49(4), pp. 1057-1073.

Duasa, J. (2007). Determinants of Malaysian trade balance: An ARDL bound testing approach. Journa/ of Economic Cooperation. 28(3), pp. 21-40.

Eicher, T.S., Mutti, J.H. \& Turnovsky, M.H. (2009). International Economics, $t^{\text {th }}$ edition. New York: Routledge.

Fouquin, K., Sekkat, K., Mansour, J.M., Mulder, N. \& Nayman, L. (2001). Sector sensitivity to exchange rate fluctuations. CEPII Research Center. (Working Paper no. 2001-11).

Gujarati, D.N. (2003). Basic Econometrics, $4^{\text {th }}$ edition. New York: McGraw-Hill Book Company.

Hacker, R. S. \& Hatemi-J, A. (2004). The effect of exchange rate changes on trade balances in the short and long run. Evidence from German trade with transitional Central European economies. The Economics of Transition, 12(4), pp. 777-799.

IHS Global Insight. (2011) South African Customs and Excise Trade Data. June 2011.

International Monetary Fund. (2006). Exchange rates and trade balance adjustment in emerging market economies. [Online] Available: http://www.imf.org/external/np/pp/eng/2006/101006.pdf. (Accessed 27 February 2009).

International Monetary Fund. (2010a). Developing a revised manual for the export and import price indices. [Online] Available: http://www.imf.org/external/np/sta/tegeipi/. (Accessed 29 0ctober 2011).

International Monetary Fund. (2010b). South Africa: 2010 Article IV Consultation-Staff Report. IMF Country Report No. 10/296. [Online] Available:

www.imf.org/external/pubs/ft/scr/2010/cr10296.pdf. (Accessed 26 March 2012).

Johansen, S. (1991). Estimation and hypothesis testing of cointegration vectors in Gaussian vector autoregressive models. Econometrica, 59(6), pp. 155-1580. 
Kamoto, E.B. (2006). The J-curve effect of the trade balance in Malawi and South Africa. Unpublished MCom thesis. Arlington: University of Texas.

Kalyoncu, H., Ozturk, I., Artan, S. and Kalyoncu, K. (2009). Devaluation and trade balance in Latin American countries. Proceedings of Rijeka Faculty of Economics: Journal of Economics and Business, 27(1), pp. 115-128.

Lal, A.K. \& Lowinger, T.C. (2002). Nominal effective exchange rate and trade balance adjustment in South Asia countries. Journal of Asian Economics, 13(3), pp. 371-383.

Liew, V.K.S. (2004). Which lag length criteria should we employ?. Economic Bulletin, 3(33), pp. 1-9.

Magee, S. (1973). Currency contract, pass-through, and devaluations. Brookings Papers of Economic Activity, 1, pp. 303-323.

Moodley, S. (2010). An estimation of the J-Curve effect between South Africa and the BRIC Countries. Unpublished MBA dissertation. Pretoria: Gordon Institute of Business Science.

Mtonga, $\varepsilon$. (2011). Did it matter? Monetary policy regime change and exchange rate dynamics in South Africa. Accepted paper for the Centre for the study of African economies $25^{\text {th }}$ anniversary conference.

Organisation for Economic Co-operation and Development Online Database. (2011). [Online] Available: http://stats.oecd.org/index.aspx?queryid=350\#. (Accessed 20 August 2011).

Phillips, P.C.B. and Perron, P. (1988). Testing for a unit root in time series regression. Biometrica, 75(2), pp. 335-346.

South African Reserve Bank. (2008). Quarterly Bulletin-December 2008. No 250. Pretoria: South African Reserve Bank.

South African Reserve Bank Online Database (2011). [Online] Available:

http://www.resbank.co.za/Research/Statistics/Pages/OnlineDownloadFacility.aspx. (Accessed 20 August 2011)

Takaendesa, P., Tsheole, T. \& Aziakpono, M. (2006). Real exchange rate volatility and its effects on trade flows: new evidence from South Africa. Journal for Studies in Economics and Econometrics, 30(3), pp. $79-97$.

Tihomor, S. (2004). The effects of exchange rate change on the trade balance in Croatia. International Monetary Fund. (Working Paper no: 04/65).

Wang, P. (2005). The Economics of Foreign Exchange and Global Finance, $I^{\text {st }}$ edition. Berlin: Springer. Yazici, M. (2008). The exchange rate and the trade balances of Turkish agriculture, manufacturing and mining. Quality and Puantity Journal, 42(1), pp. 45-52.

Yusoff, M.B. (2009). Bilateral trade balance, exchange rates and income: Evidence from Malaysia. Global Economy Journal, 9(4): Article 7. 